\title{
Water Scarcity in Communities, Coping Strategies and Mitigation Measures: The Case of Bulawayo
}

\author{
Treda Mukuhlani ${ }^{1} \&$ Mandlenkosi Taurai Nyamupingidza ${ }^{1}$ \\ ${ }^{1}$ Department of Development Studies, Midlands State University, Gweru, Zimbabwe \\ Correspondence: Treda Mukuhlani, Department of Development Studies, Midlands State University, Gweru, \\ Zimbabwe. E-mail: mukuhlanit@msu.ac.zw
}

Received: August 16, 2013

Accepted: December 16, 2013 Online Published: January 22, 2014

doi:10.5539/jsd.v7n1p144

URL: http://dx.doi.org/10.5539/jsd.v7n1p144

\begin{abstract}
This paper looks at the impact of water scarcity in communities. This paper also evaluates various mitigation measures being employed by residents themselves, local authorities, non-governmental organization (NGOs) and the government. Bulawayo, Zimbabwe's second largest city was chosen as a case study because the geographical and climatic conditions are such that it receives low and unreliable rainfall. The city has been facing water scarcity for close to a decade now. The water shortages have been recurring over and over again and this has resulted in the Bulawayo City Council introducing water shedding. This has resulted in residents being affected in many ways. Residents' health has been compromised, sanitation levels have declined and education conditions negatively impacted. The research used purposive sampling. Key informants were interviewed from the City Council, Health department, residents association and NGOs. The research covered three suburbs that are Nketa 7, Entumbane and Newton West. The research found out that the high density suburbs were the most affected by water scarcity and NGO activities were also biased to these areas. Coordinated work between the government, local authority, NGOs and the residents has ensured that a major health crisis be averted.
\end{abstract}

Keywords: water scarcity, water stress, water shortages

\section{Introduction}

\subsection{Background}

Water scarcity is not unique in Zimbabwe only but is existent in most African and Asian countries. According to Ladenburg (2012) at least $25 \%$ of countries in Africa are already experiencing water pressure; another 11 countries are expected to join them by 2025 at which time nearly 50 per cent of Africa's predicted population of 1.45 billion people will face water stress or scarcity. Nearly half of the population (300 million people) in sub-Saharan countries lack access to a supply of safe water and 41 per cent lack adequate sanitation. Water scarcity has been attributed to climate change as global warming continues to increase dry spells and shorter wet periods. Africa is especially being affected as most governments are failing to harness the little water that is there. It has been a problem of provision and distribution more than availability. This has forced many people to experience hardships with most people especially women having to walk long distances in search of water.

Bulawayo, Zimbabwe's second largest city was chosen as a case study because the geographical and climatic conditions are such that it receives low and unreliable rainfall. The average annual precipitation is $460 \mathrm{~mm}$ (Chenje et al., 1998). Runoff is also poor with a mean annual ranging from 17-19 $\mathrm{mm}$. The rivers are mostly perennial dry, and this is a general trend for rivers in Matebeleland. Water storage in large and deep reservoirs is almost impossible in most areas as the greater part of Matebeleland is acutely flat. Its population stands at nearly 1, 5 million (BCC, 2012). Bulawayo has been experiencing recurring water scarcity which has been attributed to various factors. Droughts have negatively affected water bodies. Major water sources for most of Zimbabwe's cities and towns have failed to reach full capacity due to erratic rainfalls with. Statistics obtained from an article in the Chronicle (February 22, 2013) states that Bulawayo's dams have failed to be full only reaching $45 \%$. This has resulted in major cities experiencing acute water shortages. Harare, Chitungwiza, Gweru and Kadoma have all experienced water problems which have had catastrophic results.

However, most of the causes of Zimbabwe's water problems are not entirely rooted in the climatic changes that have harshly affected Africa. It ought to be stressed that most of the challenges facing Zimbabwe's city councils 
and municipalities include financial constraints, population increase due to urbanisation, obsolete equipment, lack of coordinated political will to name just a few. It is important to note that most of the challenges facing most municipalities and councils in Zimbabwe are related and similar though the extent of impacts varies.

\subsection{Methodology}

The research used qualitative methodology where people's opinions and perspectives towards water shortages in Bulawayo were found out. A case study according to Gall and Borg (1996) is an in-depth study of instances of a phenomenon in natural context and in perspectives of the participant involved in the case being studied. The case study here was Bulawayo and there were three suburbs selected that is Entumbane, Nketa and Newton West for comparative analysis so as to come with a generalised outcome. Data collection was based on both primary and secondary sources. The primary sources included observation, unstructured interviews and questionnaires. The respondents included the city council officials from the engineering department, local clinic, school heads and representatives of residents associations as well as nongovernmental organisations. This was done so to get expert analysis on the impact of water shortages. The researcher chose interviews so as to get a close up understanding of the causes, impact and mitigation efforts done from stakeholders. Interviews were conducted with these stakeholders including some residents The secondary sources were mainly newspaper articles, journals and council minutes written about the water situation in Bulawayo. These were consulted to get historical factual data.

\subsection{Conceptual Framework}

The research was based on the Basic Needs Approach to development. The basic needs approach focuses on the provision of basic aspects that a human being needs to abstain from absolute poverty. Seers (1979) is one of the prominent scholars who have viewed basic needs as important in the attainment of development. According to the UN Intellectual History Project (2009) in 1976 International Labour Organisation held the World Employment Conference to discuss the critical issue of a people-focused development strategy. After that conference, the basic needs paradigm was internationally recognised. Basic human needs became the dominant development priority for most countries. Several aspects became the evident as being basic with shelter, food inclusive of water and clothing being emphasised on. It was realised that these needs were needed for a human being to live life without compromising his/her dignity and well being.

\section{Discussion}

\subsection{Causes of Water Scarcity in Bulawayo}

There are several factors which have led the city of Bulawayo to experience water shortages. These factors were intertwined and correlated and have been exacerbated by the structural collapse of the institutional and technical capability of both the central and local governments. The most seemingly overbearing factor had been drought which had affected the amount of rainfall. This had also been worsened by the failure to harness and preserve available water that has left the city exposed to water stress. However, there are also other relevant causes such as population growth, siltation of dams and Zinwa-BCC wrangle that has left the city at the mercy of the water shortages.

Drought has been severely felt in the Matabeleland region with the region experiencing below normal rainfall. Bulawayo has been experiencing recurring droughts for the past two decades which have negatively affected its water sources. It could be seen that due to the fact that the supply dams were receiving low inflows due to insignificant rainfall, water levels in the dams had remained critically low More intense droughts in the past decade, affecting an increasing number of people, have been linked to higher temperatures and decreased precipitation (www.unesco.org/water/wwap), Musemwa (2008) states that Bulawayo's water scarcity problems were not so much caused by derelict or inefficient water reticulation systems, but by poor rainfall because it is located in a semi-arid region and all of its dams, five dams are located in the same catchment area. The fact that all of its supply dams are located in one catchment area means that if the region faces a drought then the dam inflows would be in jeopardy.

The city's population had increased tremendously since the last dams was built in 1976 . This meant that the city has been in need of a new dam since 1986. Like, in Harare as Musemwa (2007) notes Harare's dysfunctional water systems have been worsened by rapid urban population growth and repressive forms of political interventions in city governance. The city has been growing steadily and had acquired the status of being an industrial hub. Water demand had been growing in the city for industrial and domestic use. Continuous rural-urban migration had been one of the major drivers in Bulawayo with people migrating from surrounding provinces such as Matabeleland North and South with people coming in search of employment. The failure by 
stake holders especially policy makers to plan, fund, and manage mechanisms to deliver water in proportion with the rate of urban growth represented one of the most serious threats to the future of sustainable development.

The city had also been expanding with more western suburbs' in the high density being constructed. Suburbs such as Pumula South, Emganwini and Cowdray Park had become one of the fastest growing suburbs in Bulawayo. This massive rate of urbanization had tremendous effect on the water supply. They increased water demand leading to the water stress that the city is facing. This explained why water shortages were being felt most in high density suburbs more than eastern suburbs because of its population density.

\subsection{Effects and Coping Strategies}

Water shortages have the capability of having a negative impact on the achievement of all the Millennium Development Goals (MDGs). However for this research special attention was conveyed to MDG 1 on poverty, MDG 2 on universal education and MDG on gender equality. They can lead to the increase in water borne diseases that can lead to the increase of the child mortality rate. Water shortages can also lead to an increase in gender disparities within communities as the burden of fetching water generally falls upon women whose productive roles are already a burden. They can also affect worsen the condition of HIV positive people who do not have the strength to ferry water to and from water sources. In a nutshell the problems in water supply affected each and every individual in one way or the other. Individual effects might vary but the community impact is usually severe resulting in under development and stagnation.

\subsubsection{Water Shedding}

The first and foremost response of water shortages in Bulawayo as a whole was the introduction of water shedding by the City Council in effort to stabilise the dwindling water levels in the dams. This had an enormous bearing on the residents as most of them had their normal daily routines altered to accommodate the water shedding schedule. Normal routines such as laundry and bathing were changed as residents have to wait for water supply to be restored to carry out these activities. Water shedding led to residents to look for alternative sources of water as taps remained dry for long periods with the water going for up to 96 hours. Especially affected were those who resided on higher areas who failed to get water even when the water supply was restored. This led them to be well known faces at boreholes.

Entumbane has been the one of the hardest hit areas in Bulawayo largely due its location. The suburb is situated in relatively high ground which makes the flow of water to it rather difficult. The situation has been further worsened by the water shedding which has made it difficult for water supplies to resume without problems here. This was one of the reasons why water rationing was introduced. He further state that without it Entumbane will not be receiving water at all. This has however put residents of Entumbane at a quandary as they have gone to close to a week without water. Even when they are supposed to be having water residents stated that water only came for two hours at most. This has forced many residents to opt for boreholes in the area. This has resulted in long queues in the boreholes. The research noted that women were forced to wake up as early as 3 o'clock in the morning to queue at the local boreholes. Residents are then force to store water in containers to ensure that they have at least water to drink and use for other domestic purposes. This water has proven to be helpful as it keeps residents from going to boreholes every now and then.

Also as a coping strategy, residents from Entumbane had to walk approximately two to three kilometres to Mpopoma to fetch water. Mpopoma is in relatively lower ground as compared to Mpopoma. Here residents had to forge relations with Mpopoma residents to get water. So Mpopoma had to buy water from Mpopoma residents in Mpopoma who were selling water for approximately five rand or fifty cents a bucket.

The water rationing in Newton West corresponded to the one in Nketa. However, the situation was different in that the residents in Newton West had the capacity to cope with the water rationing as most of them had boreholes in their homes. Boreholes in the area were relatively empty as compared to high density suburbs. This could be attributed to the low population density in this area. In Nketa water rationing was also in force. Residents however stated that they had been forced to buy containers so as to store water during water rationing. They also had to use the boreholes when they went without water for long periods especially when it was in the 96 hour period.

\subsubsection{Health}

Water scarcity has indirectly and directly led to the increase in water borne diseases. Failure by relevant stakeholders in addressing the water supply situation has led to the city facing a huge health crisis. According to World Health Organisation, Global Alert and Response (2008) as of 1 December 2008, the Ministry of Health in Zimbabwe has reported a total of 11735 cholera cases with 484 deaths since August 2008, affecting all 
provinces in the country. Water scarcity have led to more people falling victim to diseases such as diarrhoea after consuming water from unprotected sources. It has also forced some residents to end up using unprotected water sources to carry out their day to day household chores. This has been the case in Entumbane were residents were observed taking water from water streams for domestic purposes. It was then found out that the residents used this water for flushing toilets as they saved the one they got from the tap for consumption.

Few residents stated that they have had some water borne diseases after consuming water after the resumption of water supplies. However, there were cases were residents complained of stomach cramps after consuming water. A respondent from Nketa stated that she had suffered stomach problems. This she said was after she drank water after the city council had restored water after a lengthy water rationing programme that lasted for 96 hours. However, it could not be ascertained whether the stomach cramps were as a result of direct consumption of water or was it due to other things that were consumed by the respondents. The rate of water diseases increases significantly during periods of water shortages as people fail to follow basic sanitation rules such as boiling water. Mrs Nkala of Nketa 7 stated that she rarely boils water she collects from the local borehole as she has considered it to be safe. This has been a significant in the increase of water related diseases as residents take it for granted that the water sources are safe and water is consumable.

Few residents stated that they were using some chemicals to treat the water that they received. Those that did state that they use water guard to purify the water. Also most residents stated that they did not boil water before consumption. This could be as a result of residents assuming that the water that they receive was safe to drink. However, most residents from Newton West stated that they used chemicals to purify water. Also few residents from Newton West stated that they had suffered from water borne diseases.

According to a nurse at Municipal Clinic at Nketa 7, it had been mostly children who had been affected by the water borne diseases as compared to adults. This had been attributed by the fact that children practiced poor WASH as compared to adults. Children tended to be more casual about their hygiene as compared to adults and this made them more vulnerable. The above proved true as validated by the responses obtained from the questionnaires returned were $20 \%$ of adults stated that they had suffered from water borne diseases, however more responses were children related were the response rate was $35 \%$.

\subsubsection{Sanitation}

Water scarcity had made basic sanitation to seem more of a luxury and a very stressful process. It had become more difficult for residents to use the toilet as there would be no water to flush. Most if not all toilets in Bulawayo used the flush type of latrine which depended on the availability of consistent water supply to properly function. The failure to have reliable water supply had forced resident to find alternative means of relieving themselves most of which were unhygienic places. This had become a trend especially for school going children and the youth especially males who took advantage of the bushes surrounding the area to openly defecate which increased the risk of spreading water borne diseases. Most of these bushes in Entumbane and Nketa, especially the ones in Entumbane were an eyesore and posed potential health risk as flies moved from these areas to households thereby transmitting diseases.

\subsubsection{Hygiene}

The water shortages had also impacted negatively on the keeping of personal hygiene. Most people in the area now forewent some basic chores such as bathing and washing clothes due to erratic supply of water. Water rationing compromised personal hygiene as that person would be prone to water related diseases. In areas that constantly have water shortages people prioritise important aspects such as cooking and neglect essential aspects such as bathing. Places such as schools became areas where hygiene becomes compromised. Schoolchildren were the ones who are at most risk of poor hygiene. According to the MDG Status Report Zimbabwe (2010) in addition to cholera, the recent outbreak of typhoid in Zimbabwe is also a cause for concern as it indicates the continued challenges to the provision of clean water and good sanitation, especially in high-density urban areas.

However it has to be stated that Bulawayo has been spared the agony of dealing with any major health crisis due to its response and mitigation measures that it has undertaken in conjunction with the government and nongovernmental organizations.

\subsubsection{Sewerage Bursts}

Water shortages had also exacerbated the occurrence of burst sewages in the area. The failure to have water in the area had led to people using less water to flush. This had led to human waste pilling up within the sewer pipe which ends up leading to sewer bursts which had led to pollution in the area. According to the Millennium Development Goals Status Report Zimbabwe (2010) the reduction in water in the system has led to solidification 
and blockage of sewage systems that has led to overflow, bursts, and an increased risk of water supply contamination. In Nketa this has led to massive bursts of sewers. However, in Newton West there were no reported cases of sewerage bursts and this could be as a result of low population density as compared to high density residents. This was in contrast to the high density areas such as Entumbane were there where many sewerage bursts observed.

\subsubsection{Gender Dimensions}

Water scarcity have the capability of derailing the achievement of Millennium Development Goal 3 as the water shortages have increased the productive roles of women in Nketa as it has been mostly women who are responsible for fetching water. It has in fact seemed that they have reinforced the stereo types that fetching water is a duty for a woman or girl. This has resulted in the women and girls facing long queues waiting to get water during water rationing days. This disparity had been due to the fact that it was mostly women who were around at home for most of the tome hence the duty to fetch water has rested with them. The research also noted that it was mostly school going children that were also involved in the water fetching. It was observed that most school children went to the borehole before and after coming to school. The school children would spend close to an hour queuing for water as the queues were relatively long especially on Tuesdays when the water would have been away for between 96 and 72 hours. Of these school children it was also girls as compared to boys who were observed going to the water sources.

In an interview with a programmes officer at Bulawayo Progressive Residents Association it was derived that the failure to address the water situation was seriously affecting women and school children. School children were now spending their free time queuing for water instead of attending to their academic and extracurricular activities. According to the WHO/UNICEF Joint Monitoring Programme for Water Supply and Sanitation (JMP) poor sanitation and water shortages have many other serious outcomes of which gender discrimination leading to gender imbalance is one of them. Children - and particularly girls - are denied their right to education because their schools lack private and decent sanitation facilities. Women were forced to spend large parts of their day fetching water. Mrs Mangwiro a resident from Nketa complained that the water shortages were straining her physically as she had to carry a 20 litre container on her head whilst she was pregnant. She stated that she had no option but to do so as she lived with her husband and had no one to send to fetch water. This became a problem for women to carry such heavy loads on their heads especially when one was pregnant as that could lead to health complications for the mother and the unborn child.

Water shortages had also negatively affected women as they had increased their health care burden. Mothers are the usual primary healthcare givers in any society especially in third world countries where patriarchy is still being extensively practised. In the event that a child falls sick it is usually the mother who is responsible for taking care of that child. This affects the mothers schedule as she has to take care of the sick child as well as other children at home. At Nketa 7 Municipal Clinic it was observed that of accompanying parents $90 \%$ were female. This means that women are forced to make time in their schedules to take children to clinics in the event that they fall sick. Use of contaminated water also puts the health of women at more risk than men as they are the primary handlers of this water. Birch et al. (2012) state that the continued burdening of women in terms of healthcare tends to leave women sidelined from educational and economic opportunities. As a result women continue to lag behind in terms of development and this means that the phase of empowerment and equity will pass by with most women failing to take advantage of it due to some of these circumstances that water shortages are part of.

In Entumbane the water shortages have led to cases of sexual assault at the boreholes. This has put women at risk of being sexual harassed at water points. Women have been particularly at risk during the early morning when they wake up in the morning to queue for water at the boreholes. These boreholes are located as far as 500 metres to two kilometres from some houses and this means that women travel this distance at night to fetch water.

However the trend seems to change with age as youths have a fifty-fifty chance of fetching water. This has been necessitated by the fact that most youths spend most of their time doing nothing. It was observed that youths between the ages of 18-25 were going to fetch water without much gender disparity. This was explained by the fact that most of them were school leavers. The research in Nketa noted that $80 \%$ of respondents stated that it was female member of the family that was responsible for fetching water.

\subsubsection{Education}

During the height of the water crisis in Entumbane in 2008 the education sector was highly affected. A number of students failed to attend lessons due to the non availability of water at schools. This led to the education of 
these students to be extremely compromised. Manyewu Primary School was one such affected school that was forced to cut lessons short on days that water shortages were most acute. The research also found out that it was government schools that suffered the most as compared to council schools. Zulukandaba Primary School was more affected by the water shortages as it did not have boreholes or any other water source to rely on during water rationing. The situation has however greatly improved as all these schools have now boreholes to ensure that lessons are not compromised due to the unavailability of water.

According to Mrs T. Majazi the Deputy Headmaster at Maranatha High School in Nketa 7 (2008) was an extremely terrible year in the education sector. Water shortages in the area led to students being forced to use the urinary only and not the lavatory. This forced many students to avoid going to the toilet as it had becoming a smelly area. However she stated that they were not forced to send children back home. Maranatha is a private school which is run by the Seventh Day Adventist.

Water shortages also affected the effective carrying out of subjects such as building and agriculture which needed constant water supply. This was worsened by the fact that urban schools often do not normally have alternative water sources and no facilities to store water in order to maintain hygienic conditions at the schools during water shedding. This may have been due to the misconception that water shortages are synonymous with rural areas a scenario that the water crisis has proved to be incorrect. Teachers were then forced to postpone practicals to days that water supply was there. This could have led to the poor performance of students in these subjects during these years amongst other reasons. Private schools fared much better than government schools as they had the resources to respond to the water shortages. Schools were forced to budget for boreholes as the situation was becoming unbearable.

Also water shortages affected the studying time for students who were forced to come home after school and proceed to the boreholes to fetch water.According to Murray and Lopez (1996) the poor provision of water can limit opportunities for older children too, in part by limiting the availability of their free time. In essence it means that the time these children spend at the boreholes increase with the time that water is unavailable. Hence when the water rationing is increase it means that the school children especially the secondary going ones are affected. When they get home they are already tired. Girls are also affected more as they are the ones who also have to do the household chores.

However the trend had improved significantly of late due to mitigation efforts that have been put in place by schools. Maranatha had to drill a borehole in 2010 to enable them to carry on with lessons without much difficulty. When the situation was dire the school had to rely on water to be delivered by Bulawayo City Council Bowsers.

The situation has however improved for the better in schools in Entumbane. Lessons were progressing well with water being stored in water tanks that have been installed. Boreholes have also been drilled to supply schools with water during water rationing.

\subsubsection{Conflicts Over Water Resources}

Conflicts began to appear due to the inconsistent water supply. This led to conflicts during the height of the water rationing with residents from Nketa 9 flocking to Nketa 7 with containers to secure water. Boreholes became property that was administered by the local Residents Association. It was the mandate of the Residents Association to ensure that the boreholes were protected from vandalism and abuse. It became also the mandate of the Residents' Association to ensure that order and sanity prevailed in the Boreholes. This was after the realisation that water had become a source of conflict between residents who had previously shared the borehole.

This has led to some residents ending up going to the borehole at the dead of night to fetch water. Tinashe Dube a resident of Nketa pointed out that he would go to the borehole at night to avoid the queues and the commotion associated with the boreholes. He further stated that he was forced at times to drive to Bellevue to fetch water as the pressure there was better as it is a middle density suburb. It was however noted that the conflicts eased with the drilling of more boreholes by the City Council in the area.

In Entumbane the situation was so dire in 2008 that some unscrupulous residents began selling borehole water to the residents. They stated that they were the custodians of the water source and as such were responsible for ensuring that residents pay for using the borehole. Their main reason was the money was going to be used for repairs of the borehole in the event that it encountered a mechanical problem. This has led to conflict as other residents argue that the borehole is community property and no one is allowed to sell water to anyone. Although conflicts have however gone down as compared to 2008 increased water rationing has threatened the re eemergence of these conflicts. 
The water shortages have also added the burden on the vulnerable members of society such as the elderly, pregnant and the disabled who are already incapacitated by various burdens.

\subsubsection{Social Events}

The water shortages in Bulawayo also affected social events on the area. Events in the area such as funerals and weddings were negatively affected by the water residents. Residents had to walk long distances to the boreholes to fetch water for household chores such as cooking and laundry. The water shortages also affected sanitary conditions in the household that was undertaking the function as toilets had to be locked due to the unhygienic conditions experienced due to water shortages. Water is necessary in such events that usually attract a number of people. It is usually in these kind of events that water borne diseases such as cholera and typhoid spread. It is usually difficult to implement and enforce hygienic tendencies in an environment that has large numbers of people. It is also during such occasions that practise such as open defecation and public urination occurs. These practices then exacerbate the chances of cholera outbreaks occurring.

\subsubsection{Economic Effects}

With the continued de industrialisation of Bulawayo under the unfavourable economic environment that existed between 2000 and 2008 most people lost their formal employment. For those that decided to embark on agricultural activities they faced several challenges such as an unfavourable climatic condition and the water shortages that followed.

Water scarcity also affected the economic sector as it greatly affected economic activities in the area. Most small scale activities in Bulawayo were affected such as in brick moulding. The city council has put a strict restrictive law against the use of treated water for act ivies such as brick moulding, car washing and construction.

Nketa and Entumbane are high density suburbs that have informal businesses that thrive within it. Most of them strived on local resources to survive. They are largely businesses that are run by people who live in the area. They service the needs of the community. One such sector is the brick moulding sector that was situated in households. These entrepreneurs depended on water to mix with cement to then make the bricks. They mostly made block bricks. These were then sold to residents who would be renovating, extending or building their houses.

During the hyper inflation period the brick moulders made considerable profits as most people abandoned traditional hardware stores in procuring material for constructing. They opted for the informal sector where the payment conditions were a bit more relaxed and the material not as expensive. However the situation soon changed for the brick moulders as the City Council in an effort to reduce the depletion of treated water banned the use of treated water for commercial use in the residential areas. Those who were found were given heavy penalties for failing to adhere to the decree. Mr Moyo of Entumbane a former entrepreneur stated that he used to have a striving business which he carried out in his backyard but was limited by the water shortages that constantly affected production. He however stated that it was the high bills that he also constantly received from the City Council that prompted him to quit the brick moulding business.

The water shortages have unfortunately led to the decline in business ventures for most youths in the area who viewed brick moulding as a means of employment. Nketa High School a school within the vicinity of the Nketa community offers building as a subject and most of the students leave the school armed with the technical skill of building. However it becomes a major problem for them when they cannot utilise their skill due to the water shortages. As a result most of them remain unemployed as the industries are not employing anyone as they are also downscaling. So as a result most youths end up engaging in illegal dealings and social vices as they seek way of earning and sustaining a livelihood.

\subsubsection{Construction}

The construction sector was also been hit hard by the water shortages. However it has been noted that it had been rather the residents that have been hardly hit by the crisis. The thought of building a house or renovating has become problem in Bulawayo. Most builders in the areas insisted on the land developer to fetch his or her own water during for the construction. This had especially been a burden for the elderly land developers who have had to fetch water from the borehole as far as a kilometre away. Those that could afford it had to pay local youths to do the job. However for those who were feeling the economic crunch the burden fell squarely on their shoulder. Mrs Nyoni a resident from Nketa who was developing her four roomed house to become an eight bed roomed house bemoaned the water shortages. She stated that renovating a house in Bulawayo was more of a curse than a blessing due to the seemingly unending water crisis. She further stated that she had to pay the builders extra money for them to ferry water from the borehole that was situated near Nketa housing office. 
The effects of the water shortages on the construction sector have adverse ramifications on the social development of the community as shelter is a basic need. Shelter is an important ingredient in the promotion of human rights in as much as water. Therefore the water shortages have in effect led to the impediment of social development in the construction of shelter in the area. According Bhebhe N (The Standard, 4 November 2010) the water shortages have also affected investment possibilities for the dying city especially for those investors that are interested in sectors such as construction. This had also impacted on unemployment as it had increased the number of unemployed in the communities.

\subsubsection{Urban Agriculture}

The water shortages have also affected urban agricultural activities in the area such as market gardening. Most residents in the area were engaged in farming vegetables such as tomatoes, rape, tsunga and carrots, Most of these products were consumed at household level. These vegetables were important in improving health of residents as they could produce vegetables in their backyard at low cost. Most of the vegetables are very nutritious hence they were vital in improving the heath of the residents. Most residents also stated that they usually sold surplus produce to street vendors in the area. In a way the produce was aiding the women in gaining extra money for their personal and household use. This was however affected by the water shortages which rendered some of their activities impossible.

The water shortages also affected the production of seedlings that were being produced by women in Nketa 7 for resale. One woman a certain Mrs Nkandla sells her wares in the City Centre. She also sells some of her produce to local residents. However she complained that since the introduction of water rationing she has reduced production.

In Newton West most residents stated that their agricultural activities were not adversely affected as they relied more on borehole water for irrigation.

\subsubsection{Political Effects}

The water shortages in the area have also led to an increase in political tension. Most respondents stated that they blamed the central government for the water crisis that the city is failing. Most felt that the city was being punished for being pro MDC hence the government was purposely negating the water crisis. Few respondents blamed the local authority. However it was noted that the City Council was also not being sincere to to the grievances of the residents as most stated that the water rationing was absurd. Most residents stated that it was unfair for the City council to make e them go for 72 hours without water even if they had boreholes.

\subsubsection{Positive Effects}

However the water shortages created brisk business for some entrepreneurs. Some unemployed youths were now selling water containers in the suburb at Nketa 7 Shopping Centres. These containers were mostly being sold by women who stated that the got them from South Africa and Botswana. A 20 litre container was going for as much as 2 US Dollars. This sort of business has become a source of livelihood for these women. However it has to be noted that these women do not exclusively deal in water containers but they sell them to complement their wares as most are into vegetable seeling.

Youths were now being contracted by people who were extending their houses to fetch water from the boreholes. It was observed that youths from Nketa 8 had formed a group that deals in ferrying water for those that are constructing. It can be said that the water shortages have in a way created employment for these youths though its sustainability is questioned. Youths were also now charging residents' money to guard the boreholes at night to ensure that they were not vandalised. At Entumbane youths were also charging residents money to fetch water at the boreholes.

Selling of water had also becomeme a major source of income for some residents. Youths had taken it to themselves to sell water to those that do not have. A 20 litre bucket of water costs between 5 rand to a dollar depending on the situation. This had become a source of living for most of the unemployed youths in the high density suburbs.

The water shortages have had a huge impact in the lives of people in Bulawayo at large. Though the extent of the impact has not been as disastrous as that in Harare and other town the effects have nonetheless been felt. Mostly the effect has been felt at household level and in individual capacity. The impact has also been severely felt in the high density suburbs than in low density suburbs. Also in the high density suburbs the effects have been generally severe in Entumbane as compared to Nketa. 
The effects have been worse during the height of the water rationing that has since been between 72 and 96 hours. The effects have been declining with time with the rate of diseases declining from 2008 to 2013. This could be attributed to the projects and programmes that have been initiated by the relevant stakeholders in Bulawayo. However the continuation of water rationing means that normal routines that nee water will continue to be affected meaning that peoples' lives are still at risk. Therefore there still is a possibility of a health crisis in Bulawayo as long as people do not have access to an uninterrupted supply of clean and safe water for domestic consumption. Residents have however managed to cope with water scarcity in different ways. They have resorted to using borehole water. At ties they have even been forced to use unprotected water sources. Water conservation has also been used by residents.

\section{The Response and Mitigation Measures to Water Scarcity by Stakeholders in Bulawayo}

As postulated by UN-Water (2007) addressing water scarcity requires an integrated and multi dimensional approach to managing water resources with the aim of enhancing economic and social welfare in an equitable manner without compromising the sustainability of vital ecosystems. Thus the stake holder's involved in the mitigation process are the central government, local authority, nongovernmental organisations and the residents. The government had through its relevant ministry that is the Ministry of Water Resources and Development, Zimbabwe National Water Authority (ZINWA) and the Ministry of Finance put through initiatives such as the Mtshabezi-Umzingwane pipeline, Matabeleland Zambezi Water Project. The Ministry of Finance has played a major role in the financing of the water projects in the city especially in the rehabilitation of critical equipment at supply dams and treatment stations.

\subsection{Bulawayo City Council Initiatives}

The Bulawayo City Council had largely been involved in the mobilization of stakeholders such as the government and nongovernmental organizations. The City Council had also put forward several committees that were concerned with the water crisis in the city. The local authority had been pivotal in the coordinating of activities between the civil society and the government in finding a solution to the water shortages that have been affecting the city. The council as the relevant supplier and distributor of treated water to residents had to find resources to address the situation. Due to its limited resource capacity and the sensitiveness of the situation the council has been forced to reign in any support that it can get to solve the crisis.

Nongovernmental organisations had been instrumental in the sourcing of critical services and finance. NGOs have assisted in the introduction of programmers that have had to do with health and water system rehabilitation. The major aim was to avert a potential health crisis such as the one that hit Harare in 2009. Hence certain projects have been initiated that have to do with WASH.

The residents had largely been involved in the household mitigation measures such as engaging in prayer meetings, mobilization of pressure on to the government and the local authority through residential associations.

Bulawayo City Council as the mandated authority to supply residents with regular clean and safe water had put in place several mechanisms to respond and mitigate the water shortages in Bulawayo. These mechanisms had been held in conjunction with the government and nongovernmental organisations.

\subsubsection{Water Rationing}

The City Council had introduced water rationing as a stop gap measure that is aimed at preserving water at the dams between rainy seasons. The water rationing scheme had become somewhat of a permanent feature for the residents in Bulawayo as a whole. Water rationing had been effective in conserving water but has not been a solution. It was more of a crisis management initiative that seeked to alleviate water shortages especially to those areas that were on high ground which would not have had water unless water rationing is employed. Water levels in the dams had stayed relatively on the $50 \%$ mark Water inflows into the dams had determined the levels of dams. Water consumption had also played a role as it constituted the outflows. It had been the negative balance between inflows and outflows that had necessitated the water rationing. 
Table 1. Dam level variations during water shedding

\begin{tabular}{cccccc}
\hline Dam & Commissioned & $\begin{array}{c}\text { Carrying } \\
\text { Capacity } \mathbf{~ m}^{\mathbf{3}}\end{array}$ & $\begin{array}{c}\text { \%Volume } \\
\mathbf{m}^{\mathbf{3} 27 / 06 / 12 *}\end{array}$ & $\begin{array}{c}\text { \%Volume } \\
\mathbf{m}^{\mathbf{3}} 19 / 02 / 13\end{array}$ & $\begin{array}{c}\text { \%Volume } \\
\mathbf{m}^{\mathbf{3} 25 / 03 / 13}\end{array}$ \\
\hline $\begin{array}{c}\text { Insiza } \\
\text { Inyankuni }\end{array}$ & Yes & $173,491,000$ & 79.4 & 72.3 & 70,3 \\
Lwr.Ncema & Yes & $80,781,000$ & 13.2 & 8.6 & 70,7 \\
Umzingwane & Yes & $18,237,700$ & 45.9 & 55.1 & 40,2 \\
Upr. Ncema & Yes & $44,663,500$ & 2.4 & 40.1 & 38,4 \\
Mtshabezi** & Yes & $51,996,000$ & - & 9.5 & 10,0 \\
Total & & $\mathbf{4 1 4 , 6 2 7 , 7 0 0}$ & $\mathbf{4 3 . 1 \%}$ & $\mathbf{5 2 . 2 5 \%}$ & 100,00 \\
\hline
\end{tabular}

The water rationing hours had also been due to the consumption levels of the city. Water consumption tended to increase with a decrease in shedding hours. Average consumption per day was usually $110000 \mathrm{~m}^{3} /$ day The fluctuating levels of the dams as well as the increase in water consumption had demanded the continuation of the water rationing. Poor rains in the 2012-13 seasons had also made it necessary that short and long term mitigation measures be put in place.

Table 2. City water consumption levels during water rationing

\begin{tabular}{cccccc}
\hline City Daily Consumption & Sun 13/01/13 & Mon 14/01/13 & Sat 16/02/13 & Sun 17/02/13 & Mon 25/03/2013 \\
\hline $\mathbf{m}^{3}$ & 114015 & 74358 & 126996 & 147531 & 113000 \\
\hline
\end{tabular}

\subsubsection{Borehole Drilling and Rehabilitation}

The city council had also embarked on a borehole and rehabilitation programme that seeked to utilize groundwater in the city. Engineer I Mthunzi stated that the city council had up to March 2013 drilled 355 boreholes within the city's boundaries. The city council cannot drill boreholes or construct any water bodies outside its boundary as that becomes the responsibility of Zinwa. These boreholes are dotted around the city and have been short term mitigation measures to ensure that residents find water for daily household chores and for personal hygiene during water rationing. Most of the boreholes in Bulawayo were rehabilitated as they were drilled in the 1990s during the 1992 drought by the local authority but had been vandalized and left unused.

\subsubsection{Water Crisis Committees}

These committees were setup with the mandate of coming up with solution to the water problem facing the City. The committees were comprised of councillors, non governmental organizations such as Bulawayo Progressive Residents Association, Bulawayo Agenda, World Vision and the private sector. It is made up of stakeholders who wish to see the city's water problem addressed. The Future Water Supplies and Water Action Committee is one such committee that comprises of councillors. The committee's objectives were to monitor the water crisis, recommend possible solutions, and contribute materials, finances and expertise towards the management of the water crisis. The Water Crisis Committee met for the first time on 25 July 2012 and resolved to form 4 functional clusters to address the various water challenges, namely the Resource Mobilisation Cluster, the Monitoring and Compliance Cluster, the Advocacy Cluster and the Information Dissemination and Public Education Cluster.

Most organisations mandates usually determined their relevance to a particular cluster. For example World Vision is part of the Resource Mobilisation Cluster whilst Bulawayo Residents Association is part of the Monitoring and Compliance Cluster. The Bulawayo Council had been the central centre and has been acting as the coordinator of the crisis committee. The Water Crisis Committee through its Clusters and consultative meetings had prioritised the following sectors as seeking immediate attention;

- Improve water supply and setting up systems to pump water into storage at strategic points especially in institutions to ensure that residents get safe alternative water.

- Access funds to decrease water losses through the setting up of air release valves and incidental repairs to protect the water supply and sanitation infrastructure. 
- Supporting the activities of the Information Dissemination and the Public Education Cluster.

- Advocating for mid-term and long term projects to improve water supply to the City of Bulawayo.

\subsubsection{Partnership With Other Local Authorities}

The Bulawayo City Council had also managed to embark on a partnership with EThekwini Municipality/or Durban City Council from South Africa with the aim of improving its water system. The partnership arrangement with EThekwini Water and Sanitation (EWS) was considered to be a critical element in the continued rehabilitation and development of water and sanitation in Bulawayo. This had been after the acknowledgment of the vast technical and financial help that the Durban City Council can offer BCC. One of the critical areas noted was in the Water, Sanitation and Hygiene (WASH). The BOWSER program had been critical in fostering and expanding this relationship. Continuation of this arrangement is critical to the sustainability of many water, sanitation and health programmes. Success in the Bowser project was one such example. The partnership began in earnest in 2011. More of these partnerships are needed as they bring in more resources and technical assistance which the local authorities at the moment do not have.

\subsubsection{The Big Flush}

The big flush was an idea that was proposed by the city council to deal with sewer blockages that were being caused y insufficient water being used to flush toilets. The idea was that at a particular time all residents should flush their toilets. The agreed time was $7 \mathrm{pm}$ every day. However the response rate has note been satisfactory as some residents did not respond to the project. Poor information dissemination had been the major weaknesses as most residents did not know about the Big Flush and those that did, did not see its relevance. The city council therefore has to conduct an intensive public awareness program that touches every part of the city and sensitise the residents of the possible benefits of participating.

\subsubsection{Water Trucking}

During the height of the water shortages the City Council began transporting water to areas that were seriously affected by water shortages. Entumbane was one such area that had gone for weeks without water. The city council began transporting water in bowsers with residents queuing for the water. At Entumbane water was distributed at football grounds and schools. Each person was given 20 litres of water. This was made to ensure that more people get water. Schools and clinics were some critical areas that were prioritised by the City council in an effort to avert a health crisis. In Nketa water trucking was not done as the water situation was relatively stable and did nit warranty water trucking. The same can be said of Newton West.

\subsection{National Matabeleland Zambezi Water Project}

The National Matabeleland Zambezi Water Project was first mooted in 1914 by The Zimbabwean government. (Chronicle 12 July, 2012). This was after its realisation that the Matabeland region was a drought prone region. It understood that the region will be faced with water shortages and introduced the Matabeland Zambezi Water Project as a permanent solution to the water stress problem in the region. The project has always been a problem to implement due to financial constraints involved. The NMZWP has been a ghost project for Matabeleland with governments pledging to implement the project but to avail. The water project has been time and again been used as a campaign tool by the previous governments.

However, there have been efforts lately with the government sourcing funding from China. The project is understood to be completed in three years after the government secured \$1, 2 billion dollars from the Chinese Exim Bank with the facilitation of the Chinese government who have set aside the money (Chronicle, 12 July 2012) This comes after the Ministry of Finance through the Reserve Bank of Zimbabwe had allocated $\$ 8$ million towards the project of which that money has been set aside for pre site establishment costs. Though three years seems to be a long time it is actually a welcome development considering that the project has been in the drawing cards for 100 years. Hence one can see that eventually the project might see the light of the day after all.

The project had attracted Chinese attention with the Chinese offering financial as well as technical support for the project.

The Gwayi--Shangani dam is the first phase of the National Matabeland Zambezi Water Project. It will be the dam that will receive water from Zambezi River. The second phase would be the construction of the Gwayi-Shangani pipeline. This pipeline will be connected to a reservoir in Cowdray Park in Bulawayo. The final phase will be the construction of a $245 \mathrm{~km}$ pipeline from the Zambezi River to the Gwayi-Shangani Dam,

Revise Mtshabezi Dam was competed in 1994. At its construction the dam was not meant to supply water for Bulawayo. However due to the increasing water problems and the proximity of the dam to Umzingwane it was 
seen that connection of the dam to Mzingwane dam could augment the water levels through a pipeline. The project was seen as short term mitigation plan that would ease the perennial water shortages in Bulawayo. Connection of water from the Mtshabezi dam to Umzingwane then to Bulawayo faced many problems with technical difficulties that were attributed to supernatural activities that were occurring. A mermaid was reported to be the reason behind the failure by technicians to connect generators to pumps. According to Engineer Mthunzi Bulawayo began receiving water from Mtshabezi dam in mid December 2012 with 13000 cubic metres of water being pumped. The dam has a capacity to pump 17000 cubic metres of water every day. However, the pumping of water from Mtshabezi had been affected by power problems. This had resulted in less water being pumped to the Bulawayo as the generators could not run continuously. According to Mrs Nesisa Mpofu, council's senior public relations officer in on average, 3312 cubic metres a day are being received, against a potential of about 17200 cubic metres day (Chronicle: January 16, 2013). This put back much enthusiasm that was expected from the commissioning of the dam. The water rationing continued to be on the 72 hour basis. However it was noted that after the pumping of water from Mtshabezi Dam water rationing was reduced to from 96 hours to 72 hours hence one could appreciate the measure with regards to alleviating the water shortages.

\subsection{Nyamandlovu Aquifer}

Due to the erratic rainfall being experienced in Matebaland the government through ZINWA decided to make use of the underground water supply. Musemwa (2008) states that during the 1992 drought the Nyamandlovu aquifer was setup with 77 boreholes being sunk. Nyamandlovu aquifer is approximately $60 \mathrm{~km}$ north-west of the city. The Nyamandlovu aquifer has been used for water supply for Bulawayo for some time now. According to Engineer Mthunzi the aquifer remained one of council's major sources of water with abstraction hovering between 3000 and 5000 cubic metres of water daily. However the main weakness had been the constant breakdown of the pumps at the aquifer. Also another weakness had been the constant squabbles between the Local authority and ZINWA. Rusinga and Taigbenu (2005) note that another impediment has been the exploitation of water at the aquifer by farmers some of whom were resettled under the Fast Track Land Reform Programme (FTLRP).

\subsection{Non Governmental Organisations Initiatives}

\subsubsection{World Vision}

World Vision had also been instrumental in the mitigation of water shortages in Nketa through various programs that is has been working on with various organizations such as Dabane Trust and the Bulawayo City Council. It had largely been involved in the sourcing of funds from international donors such as UNICEF, MedAir and AUS Aid. World Vision had embarked on several projects in response to the water crisis the most effective being the Bulawayo Water and Sewerage Program commonly referred to as the BOWSER Project that was completed in 2012. The Bulawayo Water and Sewerage Program were initiated by World Vision in partnership with several stakeholders in Bulawayo. Chief amongst these was Bulawayo City Council and Dabane Trust has been the major success story in mitigating a potential health crisis in Bulawayo. The first project was planned to run from April 2010 until June 2011. However, the project only started in June 2010. The BOWSER project was funded by the Australian Aid (Aus Aid).

The project had enhanced reliability of the water supply through improving the water system. This had resulted in the improvement of circulation of water as a result of the on-going repairs of leaks. Major water leaks led to loss of non revenue water to the streets. That non revenue water meant that the city council was losing precious water as well as revenue since the water was treated and for consumption. That meant that there was a huge deficit between the levels of water at the dams and the water consumed by residents. Even though water levels at the major supply dams seemed higher that was not to be whole amount that was to be consumed. It therefore meant that estimates were inaccurate.

The BOWSER project was also effective in the rehabilitation of the sewer system in Bulawayo with the objective of reducing burst sewers and choking of household toilets. The sewer system had been affected by the water shortages as less water was being used to flush toilets. As a result most sewer pipes became choked with waste leading to massive water bursts. Therefore it became imperative for the sewer system to be cleared to reduce incidents of burst sewers which were threatening to become a health crisis.

The project also managed to see boreholes being drilled with some having motorised pumps and tanks. These were put at essential service centres such as schools and clinics. The result was the decline in reported cases of water borne diseases in Entumbane and in other high density suburbs in Bulawayo. 
The BOWSER project also identified a major loophole in the water and sanitation system in the local authority. Information dissemination and response was a problem with the city council taking long to respond to reported cases of water bursts. This led to the city losing water, what is termed as non revenue water. Information dissemination proved particularly important in the relaying of messages between the city council in particular the engineering department and residents. As a result it meant there is a reduction in the time that it has taken for $\mathrm{BCC}$ staff to respond to leaks in the system thus reducing potential loss of revenue water.

World Vision also embarked on the Participation Health Hygiene Education (PHHE) in 2012 to address the health aspect of the water crisis. The project had a limited lifespan as it ran for only 3 months due to limited funding. The project was funded by UNICEF. The project focus was on mitigating water borne diseases as well as educating residents on conserving and using safe water. Residents were educated on using water sparingly. Water conservation becomes an important aspect as it also prolongs the depletion of water in dams They were educated on using chemicals such as water guard and some tablets were distributed to residents. However despite this residents stated that the coverage of the programme was not extensive as few people benefited from the programme. Very few people were aware of the PHHE programme that was led by World Vision whereas it was quite well known in Entumbane Most resident who responded to questionnaires stated they used water guard but they bought it themselves.

World Vision together with stakeholders such as the BCC set up the Bulawayo Emergency Water Augmentation Project (BEWAP) to mitigate the water shortages in Entumbane and other suburbs in Bulawayo. The goal of the project wass to ensuring the health and wellbeing of the residents of Bulawayo, particularly the vulnerable, disabled, elderly, and those in unserved areas, by ensuring the maximum use of limited existing water and sanitation resources. The projects focused on high density suburbs that that are being most affected by the water shortages and are not getting adequate water as a result of this and water rationing. The program began in February 2013 and is projected to run for 12 months. The project also sought to improve water and sanitary and health (WASH). The project was still running hence its effectiveness could not be assessed.

However most of the projects that World Vision embarks on were inter linked and take over from where the other left from. Most of the projects fail to meet set objectives due to lack of funding. Despite these the overall impact has been positive.

\subsubsection{Dabane Trust}

Dabane Trust had been the one of the most influential non-governmental organization in Bulawayo that had been involved in bringing practical mitigation solutions. It had in conjunction with the city council been involved in the rehabilitation of water infrastructure in Bulawayo.Dabane Trust had considerable capacity and experience with urban based WASH initiatives. As a local NGO Dabane Trust had the means to engage in emergency initiatives, rapidly and effectively usually with a positive outcome. As a foundation for this Dabane had very well established links with local authorities which made it a very ideal candidate for engaging in technical assistance.

Dabane's strength in effective operation lied in its good social networking. As well as a social capacity Dabane had a strong practical and technical team. Dabane had been a strategic partner in the response and mitigation measures been undertaken by the Bulawayo City Council due to its expanse knowledge of civil and water matters. Dabane had had major works in rural areas especially in Matabeland.

In an interview with Sibonakaliso Mpala an engineer from Dabane Trust revealed that Dabane's immediate response to the water shortages was to introduce high pressure jetting equipment to significantly improve and increase the clearing of some 20,000 metres of the cities' sewage reticulation system earned the praise and respect of residents and the city council. Dabane was a founder member of the Bulawayo Sewage Task Force (BSTF), acombination of the local authority, Non Governmental Organisations and private industry which led to the formation of the BOWSER programme. Projects that target schools and the disabled have also been undertaken though the impact was difficult to assess.

\subsubsection{Bulawayo Progressive Residents Association (BPRA)}

Just like any other residents association the BPRA had been influential in the lobbying of the Government and the City Council to address the water crisis with the urgency it deserved. The association had also been responsible for the mobilization of residents to approach the local authority on the water crisis. It had been the facilitator between the residents and the city council. The association had also been responsible disseminating information to residents about water conservation. 


\subsubsection{Church of Jesus Christ of Later-Day Saints}

The church was also instrumental in the response and mitigation of the water shortages in Bulawayo. Of major significance was the donation of boreholes to the Bulawayo communities. According to http://relzim.org/category/news/html, the church donated 10 boreholes that were drilled in different parts of the city. The boreholes were drilled Pumula South, Pumula East and other high-density suburb. These boreholes have been helpful to residents as these suburbs are amongst the worst affected suburbs in Bulawayo. Many civic organisation have taken particular interest in the water scarcity problem in Bulawayo.

\subsection{Residents Response}

As individuals residents have also positively responded to the water shortages. Residents have first of all had to deal with the water rationing that was introduced by the city council. Residents were forced prior to the rehabilitation of the boreholes to store water in buckets and other available containers. Those that did not have had to buy as the water shortages soon proved to be a long term problem. People used different sets of containers for different purposes with clean containers being used to store water for consumption. Drums that were considered to be not suitable for drinking water were used to store water for other domestic chores such as laundry, bathing and flushing toilets. As the situation escalated resident used rubbish bins as water storage containers. Though this was not a healthy alternative it proved quite popular as most residents preferred those as they could store a relatively large quantity of water.

Residents were also forced to engage in water conservation as the sparingly used water. Water reuse is also an effective response measure that was embraced by the residents. For example bathing water was not thrown away but was kept to be used to flush the toilet. The same was also done for washing water which was also recycled. This proved to be an effective mitigation method at household level. Mrs Chiguvare said that another water conservation method that was employed by residents was rain water collecting. During the rainy season residents put buckets outside to collect water from their rooftops. This lessened the burden of going to the borehole frequently. This water was used for domestic purposes such as bathing and laundry.

The response and mitigation measures that have been put in place by the government, city council and the residents themselves have largely failed to end the water shortages in Bulawayo but have been greatly successful in averting a health crisis in the city. This is evidenced by the implementation of the water rationing and the continued increase in the hours of the program. In actual fact the relevant stakeholders have managed to ensure that the situation does not spiral out of control. The most effective mitigation measure has been the Bowser project which has scored considerable successes. In terms of addressing the water shortages permanently there are efforts that have been made with the availing of funds and the engagement of contractors. Short term mitigation measures have been affected by lack of coordination between Zesa, Zinwa and BCC in terms of finding common ground in pooling resources together. Failure by Zesa in prioritizing power to the pumping stations at Mtshabezi has been a major setback in utilizing water from Mtshabezi dam. However there has been a positive move by the power utility to assist where possible.

\section{Conclusion}

The water shortages though there have not resulted in significant casualties as in Harare had the potential to explode into a health crisis of high magnitude. This would be exacerbated by the lack of preparedness by the City's health department that is already under staffed and ill equipped. Furthermore the country as a whole is incapacitated to deal with any crisis $t$ due to a precarious fiscal position that we find ourselves in. Therefore there is urgent need for relevant stakeholders to deal with the water crisis with the respect that it deserves.

The government needs to prioritise the completion of the short term mitigation projects that have already been implemented but have not been completed. Financial aid needs to be extended to ZINWA to complete the rehabilitation of water works at Mtshabezi, Insiza and Nyamandlovu aquifer. Doing so will go a long way in reducing the water rationing hours that is currently hitting the high density suburbs. However of paramount importance is the completion of the National Matabeland Zambezi Water Project. The government also needs deal with the power issue that is constantly leading to irregular pumping at stations to. This needs to be addressed so that pumping at Nyamandlovu and Mtshabezi does not have to rely on generators which are costly to run and not sustainable.

The local authority needs to liaise with the nongovernmental organisations such as World Vision who have the capacity to source funding for water rehabilitation services. It needs to cast its net wider to solicitate the services of other nongovernmental organisation working locally and internationally. Also as a matter of urgency the council needs to finish the Insiza pipeline to improve water supply from Insiza to the reservoirs. The city council 
also needs to beef up security at its major water works to deter vandalism of critical equipment. Especially important are the Nyamandlovu aquifer and the pumping station at the major supply dams.

The local authority is also facing financial constraints and needs to recover the money it owes from residents. However the council needs to first recover the lost faith that the residents have in their system by embarking on a marketing and sensitisation rive that will conscientise the residents about the benefits of paying their bills on time and constantly. To begin with it needs to focus on the adjusting of its bills since dollarization and the rehabilitation of old and faulty meters. It needs to come up with a similar or better scheme that the Zimbabwe Electricity Distribution and Transmission Company (ZEDTC) did. This will go a long way in addressing the financial problems that the council is facing and use the money to rehabilitate and improve the existing water system.

The city council needs also to embark on more WASH programmes to ensure that the looming health hazard is nipped in the bud. It needs to focus attention to its primary schools that are scattered around the city. It needs also to utilise its municipal clinics in the suburbs to be call centres or command centres for sensitisation campaigns. This is necessary as the nurses are already equipped to deal with the knowledge and skills to disseminate correct and practical information.

\section{References}

\section{Interviews}

Mr S Mpala, Engineer at Dabane Trust on March 23, 2013 at Dabane Trust offices.

Mrs T Majazi, Deputy Head of Maranatha High School in Nketa 7 on Wednesday March 27, 2013 at Maranatha High School Engineer Ian Mthunzi, Bulawayo City Council's Water Engineer at Tower Block on Wednesday 27 March 2013.

Mr Ncube, Vice Residents Chairperson of Nketa 7 Residents Association on 28 March 2013.

Mrs Mangwiro, resident from Entumbane at 31557 Entumbane B.

Mr Moyo, Entumbane entrepreneur, March 29, 2013.

Mrs Nkala, Resident from Nketa 7, March 29, 2013.

Mrs Chiguvare, resident from Nketa 7 March 29, 2013.

Mr Chasi, a resident from Newton West on April 21, 2013.

Nurse from Nketa Clinic, March 23, 2013.

Programmes officer, on Monday March 25, 2013 at BPRA offices at Laff House.

\section{Newspapers}

(Newsday, December 19, 2012) Census results queried.

(The Standard, November 4, 2010) Matebeleland water woes smokescreen for de-industrialization.

(The Standard, January 10, 2010) Obsolete machinery behind Byo's water woes.

(Newsday, December 19, 2012) Census results queried.

(Chronicle, February 22, 2013) City dams 45 percent full.

(Chronicle, January 19, 2013) City water shedding schedule to stay.

(Chronicle, January 13, 2013) BCC aquifer squashed.

\section{Secondary Sources}

Birch, E. L. (2012). The Urban Water Transition: Why We Must Address the New Reality of Urbanization, Women, Water, and Sanitation in Sustainable Development inwH2o. The Journal of Gender and Water, 1(1), 6-7.

Borg, W., \& Gall, M. (2000). Educational Research Longman. New York.

Brocklehurst, C. (2011-2012). Water, Sanitation, Hygiene and the Millennium Development Goals in The Global Water Crisis: Addressing and Urgent Security Issue, Papers for the Inter-Action Council, 2011-2012, Edited by Harriet Bigasetal, Hamilton, Canada: UNU-INWEH.pdf.

Brundtland, G. H. (2012). Water for Health - Taking Charge, WHO World Water Day Report 2008, Geneva, Switzerland, 2008. Retrieved October 31, 2012, from http://www.worldwaterday.org 
Bulawayo Water and Sewerage Program (BOWSER). (n.d.). Monitoring and Evaluation Report, September 2011. pdf

FAN Rights to water and Sanitation: A handbook for activists, FAN Global. (2010). Retrieved from www.freshwateraction.net.pdf

FAO Corporate Document Repository, Fisheries Management of small water bodies in seven Countries in Africa, Asia, Zimbabwe, The Country. Retrieved from http://www.fao.org/docrep/W7560E/W7560E02.html

Jones, L., \& Somekh, B. (2005). Research methods in the Social Sciences, In B. Somekh \& C Lewin (Eds.), Sage Publication, London.

Landenberg, D. (n.d.). The facts on Water in Africa, World Wildlife Fund- Living waters. Retrieved from http://www.panda.org /living waters pdf

Mangizvo, R. V., \& Kapungu, N. (2010). Urban Domestic Water Crisis In Zimbabwe: The Case of Kadoma City. Journal of Sustainable Development in Africa, 12(8).

Municipal Reporter, Harare gets $\$ 100$ million for water, The Herald Online, 16-23-2012. Retrieved from http://www.herald.co.zw/

Murray, C. J., \& Lopez, A. D. The Global Burden of Disease: A Comprehensive Assessment of Mortality and Disability from Diseases, Injuries and Risk Factors in 1990 and Projected to 2020. Boston, MA: Harvard University Press, 1996 in F Tarrass and M Benjelloun,The effects of water shortages on health and human development. Retrieved from http://rsh.sagepub.com/content/132/5/240

Musemwa, M. (2008). The Politics of Water In Post-Colonial Zimbabwe, 1980-2007, Seminar paper presented at the African Studies Centre, University of Leiden, The Netherlands, June $19^{\text {th }}, 2008$.

Muta'a Hellandendu, J. Health Implications of Water Scarcity In Nigeria, Department of Sociology, Ahmadu Bello University, Zaria in European Scientific Journal August edition vol. 8, No.18 ISSN: 1857 - 7881 (Print) e - ISSN 1857- 7431.pdf

Mutsvangwa, C. (2001). Management of water resources in Bulawayo City, 27th WEDC Conference, People and Systems for Water, Sanitation and Health, Lusaka Zambia, 2001.

PLoS Medicine. Hygiene, Sanitation and Water: What needs to be done? November 2010, Volume, Issue 11.

Prüss-Üstün A et al. (2008). Safer water, better health: costs, benefits and sustainability of interventions to protect and promote health. World Health Organization, Geneva, 2008.

Rusinga1, \& Taigbenu, A. E. (2005). Groundwater resource evaluation of urban Bulawayo aquifer. Water SA, 31(1). Retrieved January, 2005, from http://www.wrc.org.za

Special http://blog.euromonitor.com/2010/09/special-report-global-water-shortages-will-pose-major-challenges.html

Tarrass, F., \& Benjelloun, M. (2012). The effects of water shortages on health and human development. Perspectives in Public Health, 132(5). Retrieved from http://rsh.sagepub.com/content/132/5/240

Tashakkari, L., \& Teddlie, M. (2003). Sage handbook of Mixed Methods in Social and Behavioural Research (2nd ed.). USA, 2010.

Tshuma, M. (2012). Latter-Day Saints donate 10 boreholes to BCC. Retrieved April 17, 2012 from http://relzim.org/category/news/html

UNDP. (2006). Water scarcity, risk and vulnerability, Human Development Report 2006.

United Nations Development Programme. (2006). Beyond Scarcity: Power, Poverty and the Global Water Crisis, The Human Development Report.

United Nations Development Programme (UNDP). (2010). Millennium Development Goals Status Report Zimbabwe, 2010.

United Nations Department for Policy Coordination and Sustainable Development, Information Provided by the Government of Zimbabwe to the United Nations Commission on Sustainable Development Fifth Session 7-25 April 1997 New York. Retrieve from http://www.un.org/dpcsd/earthsummit

UN Intellectual History Project. (2009). The UN and Human Development, Briefing note Number 8, July, 2009. Retrieved from http://www.UNhistory.org 
UN-Water. (2007). World Water Day,coping with water scarcity challenge of the twenty - first century. Retrieved from http://www.worldwaterday07.org.html

UN-Water Thematic Initiatives, Coping with water scarcity, A strategic issue and priority for system-wide action, Retrieved August, 2006, from http//:www.unwater.org

UN World Water Assessment Programme and UN Human Settlements Programme (Un-habitat), Water for sustainable urban human settlements, UNESCO-WWAP, Paris.

WHO/UNICEF, Joint Monitoring Programme, Geneva and New York, 2008.

World Heath Organising, The International Decade For Action, Water For Life - 2005-2015, Coping with Water Scarcity, World Water Day 2007. Retrieved from http://www.un.org/waterforlifedecade

World Health Organisaton, Global Alert and Response (GAR), Cholera in Zimbabwe. Retrieved from http://www.who.int/entity/csr/en/.html

Zimbabwe National Statistic Agency, Census Preliminary Report 2012, Harare, Zimbabwe.

\section{Copyrights}

Copyright for this article is retained by the author(s), with first publication rights granted to the journal.

This is an open-access article distributed under the terms and conditions of the Creative Commons Attribution license (http://creativecommons.org/licenses/by/3.0/). 